\title{
Thelohanellus (Myxozoa: Myxosporea) infection of the scales in the European wild carp Cyprinus carpio carpio
}

\author{
Alexander Moshu ${ }^{1, *}$, Kálmán Molnár ${ }^{2}$ \\ ${ }^{1}$ Institute of Zoology, Academy of Sciences of Moldova, Academiei str. 1, 2028 Chişinău, Republic of Moldova \\ ${ }^{2}$ Veterinary Medical Research Institute, Hungarian Academy of Sciences, H-1581 Budapest, PO Box 18, Hungary
}

ABSTRACT. Thelohanellus infection of the scales of the European wild carp Cyprinus carpio carpio L. is reported for the first time in Europe. Comparative morphological and histological findings are described. Plasmodia and spores found in the fins of cultured common carp fingerlings and those detected in the scales of 2-to $>4$-yr-old European wild carp belong to the same species. The morphological characteristics of the spores and histological analysis of plasmodial location suggest that the species is identical with Thelohanellus nikolskii Achmerov, 1955. The authors regard $T$ cyprini Hoshina \& Hosoda, 1957 and T. callisporis Ky, 1971 as junior synonyms of T. nikolskii Achmerov, 1955.

KEY WORDS: Thelohanellus nikolskii - Myxosporea Scale - Fin - Cyprinus carpio - Taxonomy Histopathology

\section{INTRODUCTION}

Up to now, more than 40 species belonging to the genus Thelohanellus Kudo, 1933 have been reported in the literature as parasites of about 50 fish species. They are generally histozoic and highly host-specific parasites. Among species known from various fish hosts (e.g. from the genera Labeo and Barbus), an especially high number of host-specific Thelohanellus spp. has been described in the common carp Cyprinus carpio

Achmerov (1955, 1960) described 5 new species (Thelohanellus nikolskii from the fins, $T$. amurensis from the liver, $T$. acuminatus from the gills, $T$. dogieli from the skin, and $T$. hovorkai from the peritoneum) from the Amur wild carp Cyprinus carpio haematopterus Temminck et Schlegel. The number of Thelohanellus species known to parasitize the common carp was increased by Hoshina \& Hosoda (1957) and Egusa \& Nakajima (1981), who described T. cyprini from the fins and $T$ kitauei from the intestinal wall, respec-

\footnotetext{
•E-mail: bio@mdearn.cri.ma
}

tively, of cultured common carp raised in Japan. Two additional species, T. callisporis and T. acuminatus, were found in this fish species by Ky (1971) in Vietnam. Besides these species, some other Thelohanellus spp. (T. fuhrmanni, T. oculileucisci, T. pyriformis and Thelohanellus sp.) described from other fishes have been reported to occur in common carp (Bauer 1948, Petrushevsky \& Bauer 1948, Donec \& Shulman 1984, Iskov 1989, Moshu 1993). On the basis of the high variability observed in the shape and size of spores and polar capsules, Shulman $(1962,1966)$ and Donec \& Shulman (1984) considered $T$. nikolskii, $T$. hovorkai, $T$. amurensis and $T$. cyprini to be synonymous with $T$. dogieli, and synonymized $T$. acuminatus with $T$. fuhrmanni (Auerbach, 1909).

Thelohanellus spp. parasitic in the common carp can be differentiated relatively easily by the morphological characters of their spores and the location of plasmodia in the tissues and organs. In Europe, Jeney (1979) was the first to detect a Thelohanellus species in common carp. Accepting Shulman's (1966) opinion, she identified the species reported from Hungarian fish farms as Thelohanellus dogieli Achmerov, 1955. Later on, however, this species was classified as Thelohanellus 
nikolskii Achmerov, 1955 (Jeney \& Molnár 1981, Molnár 1982, Molnár \& Kovács-Gayer 1981-1982, 1986). These authors pointed out that in the majority of cases a mixed infection existed, in which $T$. nikolskii was found together with $T$. hovorkai parasitic in the connective tissue of different organs. Thelohanellosis attributed to $T$. dogieli was described in 5-yr-old common carp in Yugoslavia (Hacmanjek 1985). The infection was localized to the gill tissues, fins, kidneys, stomach, swimbladders, and serosa of the internal organs. In Moldova, $T$ nikolskii infection was first recorded by Trombitsky et al. $(1983,1990)$, and the biology and pathogenicity of the parasite have been studied in rearing ponds since that time.

The pathological changes caused by Thelohanellus nikolskii were studied by Molnár (1982), who reported that this parasite forms huge plasmodia developing in a cartilaginous capsule constituted by perichondrial cells of the finrays. The plasmodia and the spores formed inside them caused severe cartilage deformity which could be seen even with the unaided eye. Desser et al. (1983) described the ultrastructural features of sporogenesis of $T$. nikolskii from the fins of common carp. Thelohanellus kitauei, a parasite found by Kitaue (1980) and described by Egusa \& Nakajima (1981), has similarly great pathologic importance. This parasite is the causative agent of the intestinal giant cystic disease of the common carp, which is a well-known disease in Japan and Korea (Rhee et al. $1990 \mathrm{a}, \mathrm{b})$.

Morphological and histological studies on Thelohanellus infection of the scales in European wild carp are reported in this paper.

\section{MATERIALS AND METHODS}

Fish material included fingerlings and 1-yr-old specimens of pond-cultured common carp Cyprinus carpio L. collected from farm ponds and water reservoirs of Moldova, as well as 2- to >4-yr-old wild carp Cyprinus carpio carpio L. from natural waters (Lakes Cahul, Ialpug, Chitai and Sasâc). From the latter lakes a total of 56 specimens were examined. In addition to examining the fins and scales of the collected fish, a complete parasitological dissection was performed on 3309 specimens of carp in the period from 1986 to 1995.

Samples taken from different organs during dissection were compressed between 2 slides and examined under a microscope for the presence of spores or plasmodia. In positive cases the location of cysts and free spores was recorded, the spores ( $n=50$ to 80 ) were measured in fresh and fixed material preserved in glycerol-gelatine or ammonium picrate solution, and line drawings were made and photographs taken. Fins and scales infected with developing or spore-filled plasmodia were fixed in $10 \%$ buffered formalin or Bouin's solution. The fixed material was embedded in paraffin wax, cut into $4 \mu \mathrm{m} \mathrm{sec-}$ tions, and stained with haematoxylin and eosin (H\&E) or by Azan's and Giemsa's techniques. Micrographs were taken in a Zeiss Jenaval microscope.

\section{RESULTS}

From July to early September plasmodia were found on the fins of 2-to 3-mo-old carp fingerlings collected from ponds and water reservoirs. The prevalence of infection proved to be 93 to $100 \%$ while its intensity was 2 to 283 cysts per fish. Fin infection was seldom found in 1- to 2-yr-old wild carp; however, some cysts did occur on these fish in late autumn and early spring, though at a low prevalence and intensity of infection. The measurements and morphological characteristics of spores released from plasmodia developing on the fins corresponded to those given by Achmerov (1955. 1960), Molnár (1982), Trombitsky et al. (1983), Cirković (1986) and Dyková \& Lom (1988) for the identification of Thelohanellus nikolskii (Table 1).

It should be noted that the highest variability in shape and size was shown by the spores of Thelohanellus nikolskii populations from the fins (Table 1). Spores of larger size were more frequently recorded from older fish than from fingerlings. A localitydependent variation in the morphometrical (principally size) characteristics of spores was also observed. The highest variation in the shape and size of spores was detected in carp from the Vatra reservoir near Chisinau (spores: $16.2-21.6 \times 5.7-13.5 \times 6.0-10.0 \mu \mathrm{m}$; capsules: $5.0-8.4 \times 3.7-6.8 \mu \mathrm{m})$. That reservoir has relatively poor ecological conditions.

Plasmodia on scales were found only in wild carp Cyprinus carpio carpio. These round plasmodia reaching $3 \mathrm{~mm}$ in diameter were located at the outer margin of the scales (Fig. 1). Neither cysts nor their traces were observed on the fins of these fish. Only 15 out of the 56 fish examined in the 4 different habitats in May and June of 1992 and 1993 proved to be infected by plasmodia (examined/infected: 17/5, 8/2, 12/2 and 19/6, for Lakes Cahul, Ialpug, Chitai and Sasâc respectively); thus, the overall prevalence in the 4 localities was almost $26 \%$. At the same time, the intensity of infection was extremely high, and almost every scale was infected by 4 to 7 plasmodia.

Both in fin and scale infection solitary spores were detected in the gut, gills, kidney, gallbladder, nasal pits, and other organs

The shape and size of spores obtained from mature plasmodia in the scales roughly corresponded to Thelohanellus nikolskii spores collected from the fins. The 


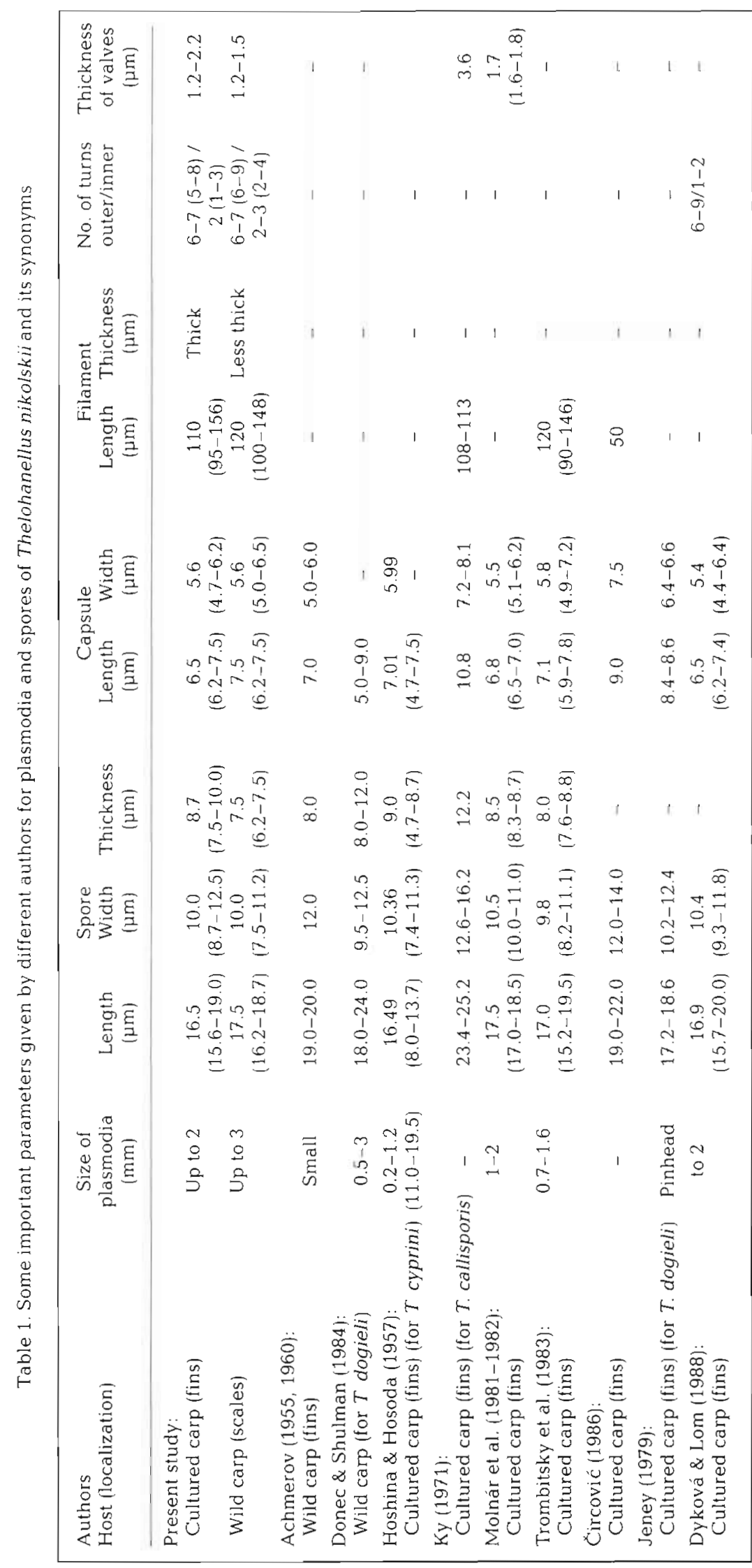

slight differences that were observed between spores from fins and those from scales were the following: The dimensions of spores developing in scale plasmodia were less variable. These spores were slightly longer and thicker but somewhat narrower than those obtained from the fin cysts. Spores from the scales had a larger subsphaerical polar capsule containing longer and finer polar filaments. These latter had a larger number of turns inside the capsule (Table 1, Figs. $2 \& 3$ ). In both cases the sutural markings were more noticeable in immature spores and in permanent preparations.

\section{Histology of the normal fins and scales}

Histologically the finrays are built up from fibrous cartilage (a calcified collagen) and composed of 2 hemisegments (lepidotrichia). Cartilaginous finrays are located inside a fibroblast layer of the dermis rich in collagenic fibres. Cells surrounding the fibrous cartilage of the finrays (hemisegment-forming cells) excrete collagen to the outer surface of the finrays. They differ from other fibrocytes of the dermis by their larger nuclei. Externally the dermis is covered by multilayered epidermis overlying a membrana basialis.

The structure of the scale resembles that of the finrays in many respects. Like that of the finrays, the firm structure of the scales inside the dermis consists of a plate of calcified collagen (Fig 4). This plate is covered both episquamally and subsquamally by a single layer of scleroblast cells located inside a connective tissue rich in collagen (Figs. $5 \& 6$ ) Episquamally the connective tissue joins the membrana basialis of the multilayered epithelium of the epidermis, while subsquamally the collagenrich connective tissue continues in a loose connective tissue and joins the musculature. Around the edge of the scales, the epithelium, which is rich in goblet cells, runs under the cartilaginous plate and covers, in a small part, also the subsquamal region as well (Fig. 7). 


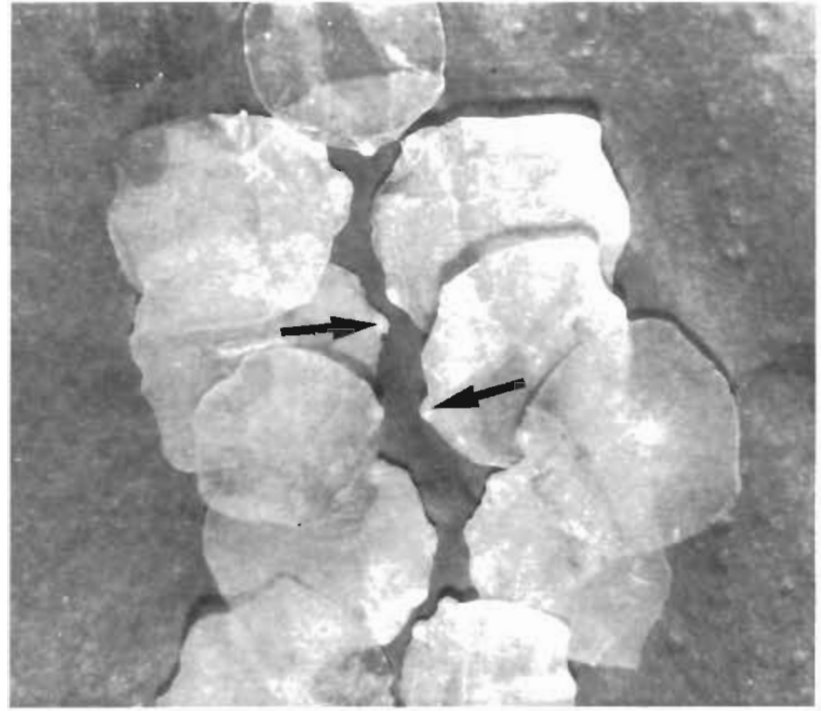

Fig. 1. Thelohanellus nikolskii infection of scales. Plasmodia are located at the outer margin of scales (arrows) (natural size)

\section{Histology of the infected fins and scales}

Plasmodia in the fins developed on the surface of the finrays inside a calcified collagenic capsule, the structure of which corresponded to that of the lepidotrichia (hemisegments). This fibrous cartilage cyst was also bordered by hemisegment-forming cells (perichondrial cells) which separated the plasmodium from the surrounding collagen-rich fibroblast zone (Figs. 8 \& 9). Cartilagc islets detached from the hemisegment and surrounded by hemisegment-forming cells were also seen inside this connective tissue. Mature plasmodia were filled with spores; developing ones, however, contained spores only in the central region of the plasmodium, while in the periphery a layer of vegetative stages and pansporoblasts was located.
The development of plasmodia in the scales is also associated with the calcified collagen (Figs. $7 \& 10$ ). The plate around the plasmodia breaks into pieces (Fig. 10), and calcified islets appear inside the connective tissue around the plasmodium similar to those seen in the finrays (Fig. 5). The wall of the cyst around the plasmodium also contains a thin layer of calcified collagen, but the cyst-forming scleroblast cells are more elongated than cells with a similar function in the fins (Figs. 5 \& 6). The plasmodium structurally corresponds to those in the fins, as the central parts of developing plasmodia are filled with young spores while at their periphery vegetative developmental stages and pansporoblasts are found (Fig. 6).

\section{DISCUSSION}

Since Achmerov (1955) called attention to the location-dependent variability of Thelohanellus spp., data on host and tissue specificity have become-in addition to differences in spore morphology - a highly useful tool for the identification of different species. This allows an easy differentiation of the best known species ( $T$. nikolskii developing in the finrays, $T$. hovorkai found in the connective tissue, principally in the adventitia of the blood vessels, and the typical gut parasite $T$. kitauei) without a detailed examination of the morphological characters (Egusa \& Nakajima 1981, Molnár \& Kovács-Gayer 1986).

Based upon this fact, spores collected from scale cysts should first be compared with those of species (Thelohanellus dogieli, T. callisporis) described from the same location. Despite its similar location, $T$. dogieli can easily be differentiated from our species on a morphological basis, as the spores of $T$. dogieli are characterised by a relatively small sporoplasm and an extremely large polar capsule. In this respect $T$. dogieli

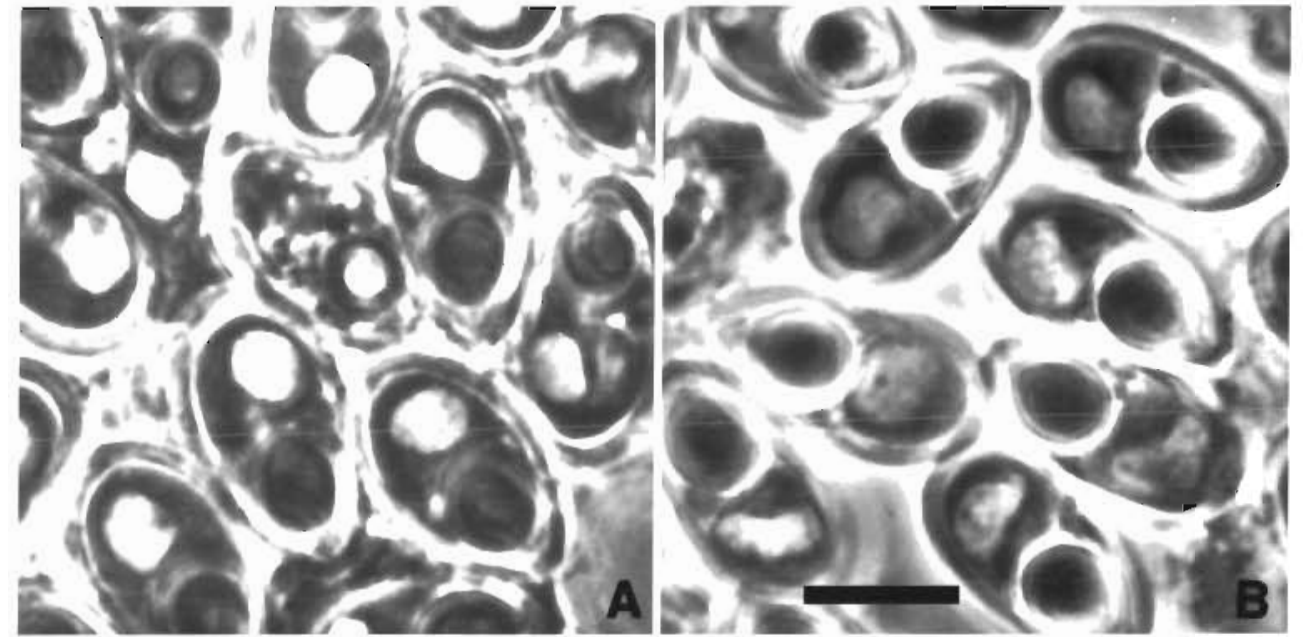

Fig. 2. Thelohanellus nikolskii. Spores (A) from fins, (B) from scales (bar $=1.0 \mu \mathrm{m})$ 
Fig. 3. Thelohanellus nikolskii Schematic illustration of the spores (A) from the fins and (B) from the scales of the common $\operatorname{carp}(a, b, c,=$ frontal, $d=$ sutural, and $c=$ upper views) (bar $=5 \mu \mathrm{m})$
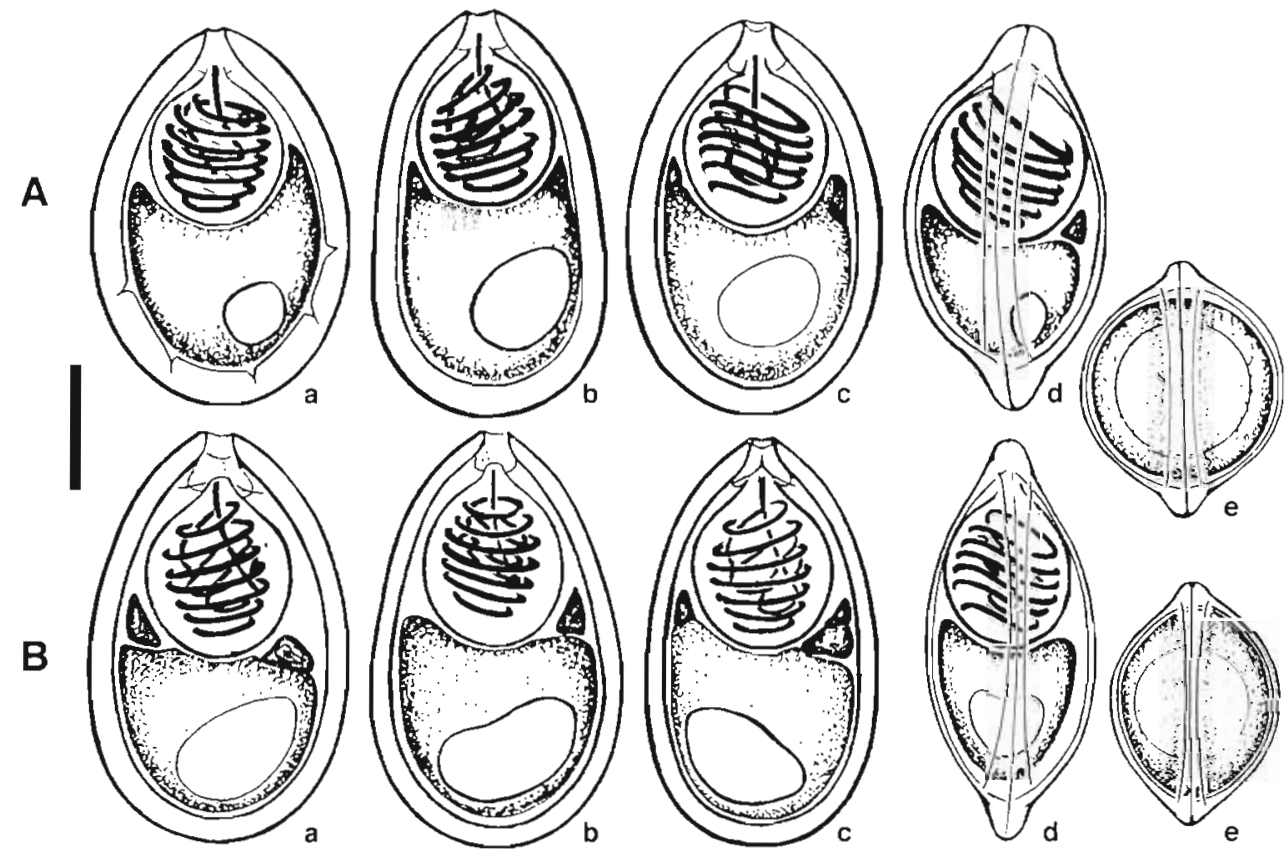

shows closer resemblance to $T$. kitauei, but the 2 species sharply differ in organ and tissue specificity. As regards spore morphology, our species closely resembles $T$ callisporis found by Ky (1971) in the skin of cultured common carp in Vietnam. Although in his original description Ky (1971) indicated larger dimensions for the spores of his species, studying Ky's material deposited in the protozoological collection of the Russian Academy of Sciences in St. Petersburg we found similar spore measurements as those obtained for spores from Moldovian fin and scale infections. When re-examining Ky's slides (e.g. slide Nr, 1227, T. callisporis, det. Ha KY, Cyprinus carpio, skin and gills, pond farm 'Hanoi', 1965, leg. Ha Ky), we obtained the following measurements: spore size: $17.5-18.7 \times 9.3 \times$ $12.0 \mu \mathrm{m}$; capsule size: $5.0-6.2 \times 5.0-6.8 \mu \mathrm{m}$; turns of filaments in the capsule: $7-8$ outer and 2 inner. These data correspond to those of T. nikolskii; therefore, we regard T. callisporis described by Ky (1971) as a syn- onym of T. nikolskii. The literature cited by Ky (1971) reveals that he overlooked Achmerov's (1955, 1960) papers and relied on the data reported by Shulman (1962, 1966), who synomyzed most of Achmerov's species with $T$. dogieli. This is supported by the fact that Ky (1971) described another Thelohanellus species from the gills of the common carp by the name of $T$. acuminatus, which corresponded both in shape and location to the species described under the same name by Achmerov (1955).

An analysis of the Thelohanellus infection of $\mathrm{Mol}$ dovian wild and cultured carp populations has led us to the conclusion that both fin and scale infections were caused by $T$. nikolskii. The differences between stages of $T$. nikolskii found on fins and scales are not substantial. The slight differences observed in size and shape do not exceed the limits of natural variations typical of populations or species. Perhaps the small discrepancies in morphometry and in the seasonal occurrence of
Fig. 4. Cyprinus carpio carpio. Normal structure of the carp skin. (a) Epidermis rich in goblet cells, (b) episquamal connective tissue layer of collagen-forming fibroblasts, (c) calcified plate of the scale, (d) detached layer of scleroblast cells, (e) subsquamal connective tissue layer of collagenforming fibroblasts, (f) loose connective tissue. $H \& E, \times 150$

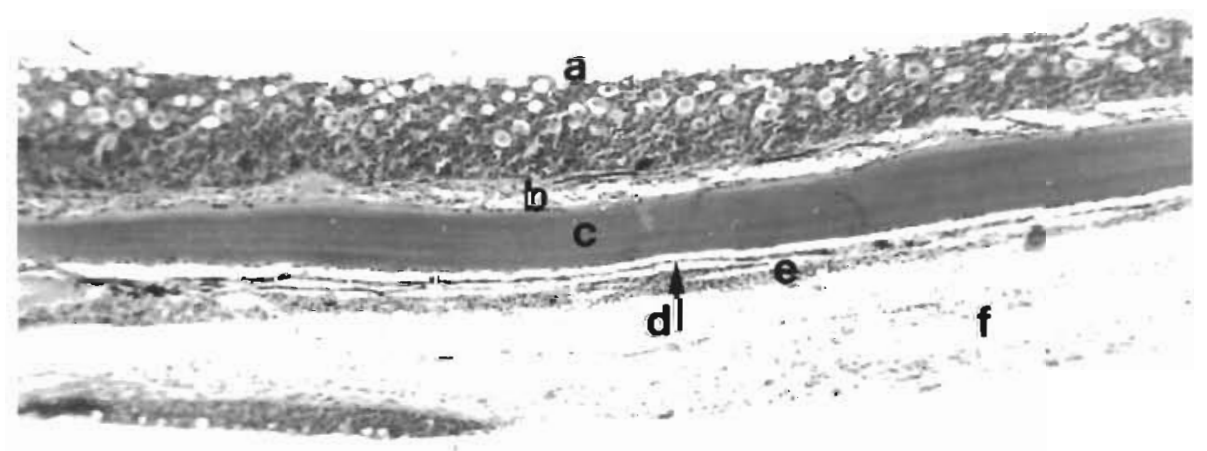




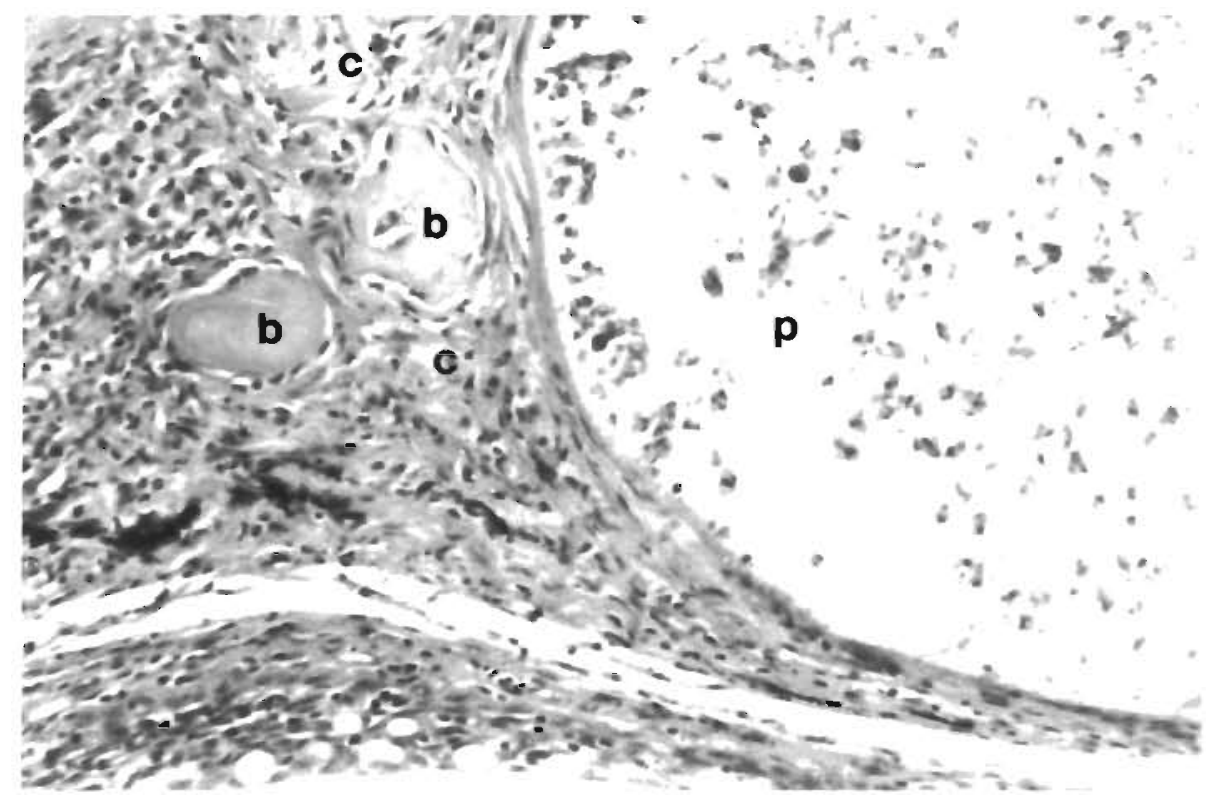

Fig. 5. Cyprinus carpio carpio infected with Thelohanellus nikolskii. Part of a scale plasmodium (p) surrounded by connective tissue (c) and deformed parts (b) of the calcified scales. $H \& E, \times 300$ the parasite are influenced by differences in location, ecology, and age of the host.

The Thelohanellus species found by us in the fins of the common carp in Moldova corresponds to $T$. nikolskii both in morphology and location, but in some respects it differs from the material collected in Hungary (Molnár 1982, Desser et al. 1983). The collagenic (cartilaginous) cyst around plasmodia in the material collected in Moldova proved to be slightly thinner than in the Hungarian material, and the layer of hemisegment-forming cells (perichondrial cells) proved to be less compact and was composed of more elongated cells.
The identification of Thelohanellus plasmodia in the scales is more problematic. Achmerov (1960) and Ky (1971) described the skin as the typical location for $T$ dogieli and T. callisporis, respectively. As these authors had scaled carp material, we can presume that in their designations the term 'skin' also included the scales. They did not specify the exact tissue of the skin or scales in which the plasmodia of these parasites were found. Achmerov (1955) only mentioned that the parasite '...forms in the skin a different number of cysts, which are visible through the skin and scales'.

It is obvious that there are considerable morphological differences between the spores of Theloha-

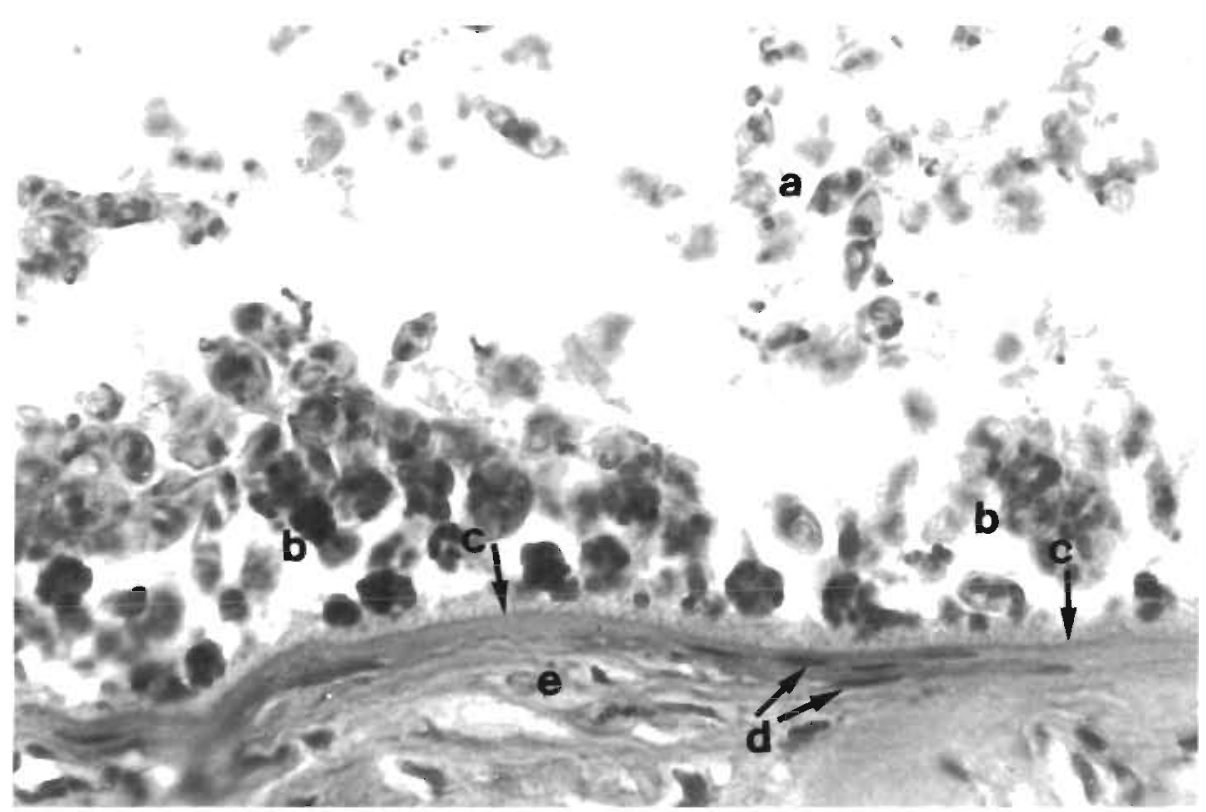

Fig. 6. Cyprinus carpio carpio. High magnification of the peripheral part of a scale plasmodium. (a) Matured spores. (b) pansporoblasts, (c) cartilaginous (collagenic) capsule, (d) scleroblast cells, (e) collagenic connective tissue. $H \& E, \times 750$ 
Fig. 7. Cyprinus carpio carpio Cross section of scales infected with Thelohanellus nikolskii plasmodia (p). The multilayered epithelium folds back and runs under the scales in a short part (arrow) $H \& E, \times 23$

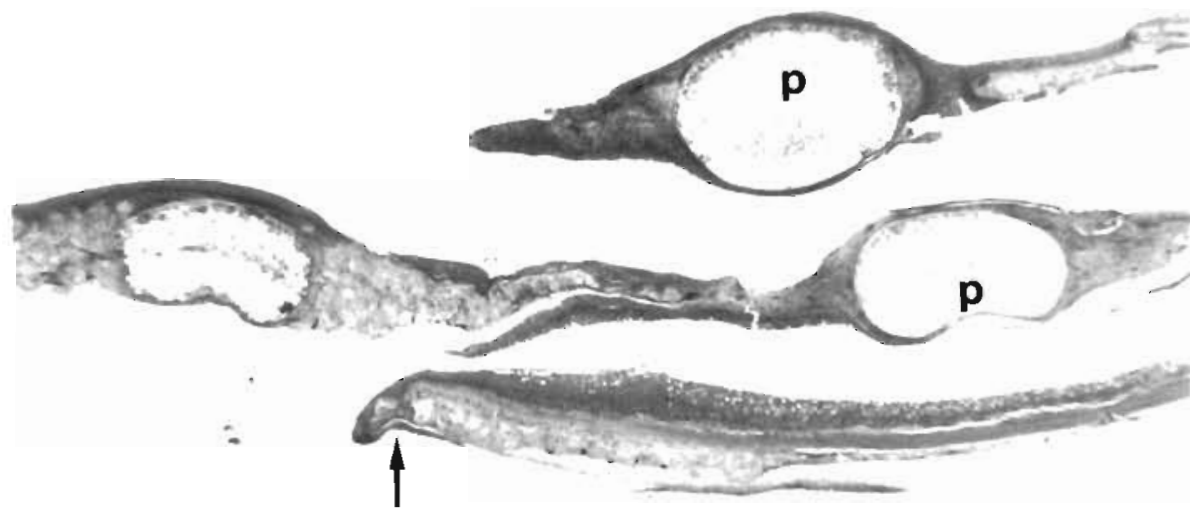

nellus dogieli and $T$. nikolskii. $T$. dogieli also differs from $T$. callisporis, which, however, closely resembles T. nikolskii. Morphologically the species found by us in the scales corresponds to $T$. nikolskii and a species segregation could only be suggested by differences in location.

Molnár (1994) characterised myxosporeans as host, organ and tissue specific organisms. Organ specificity is determined by tissue specificity. The importance of location in this case is, therefore, diminished by the fact that the hemisegments in the fins are formed by the same modified collagen producing fibrocytes which participate in forming the calcified (cartilaginous or bony) plate of the scales. The cartilaginous cyst wall around the plasmodia is produced by the same type of cells. Lanzing (1976) named these fibrocytes of the fins hemisegment-forming cells, while Molnár (1982) termed them perichondrial cells. Based on their origin and function, these cells correspond to those modified fibrocytes of the scales which Lanzing \& Wright (1976) refer to as scleroblasts. Lanzing (1976) stressed that 'there did not appear to be an intrinsic difference between calcification in fish scales, finrays and mammalian bone'. Our results prove that the Thelohanellus species found in the scales is a typical parasite of the cartilage of collagenic origin, and forms its plasmodia within a cartilaginous capsule just like T. nikolskii in the fins. Although the cartilaginous capsule in the scales proved to be thinner than those in the fins, and scleroblast cells slightly differed from the perichondrial cells of the fins, we are of the opinion that the species found in the scales is identical with $T$ nikolskii Achmerov, 1955, and differences seem to be only virtual. The formation of the cartilaginous layer in the fins and scales is not associated with the activity of chondroblasts; however, in both cases the cartilagi-
Fig. 8. Cyprinus carpio carpio. Cross section of a finray infected by Thelohanellus nikolskii. (a) Hemisegments, (b) broken parts of the cartilage, (c) $T$ nikolskii plasmodium with spores. $H \& E$, $\times 190$

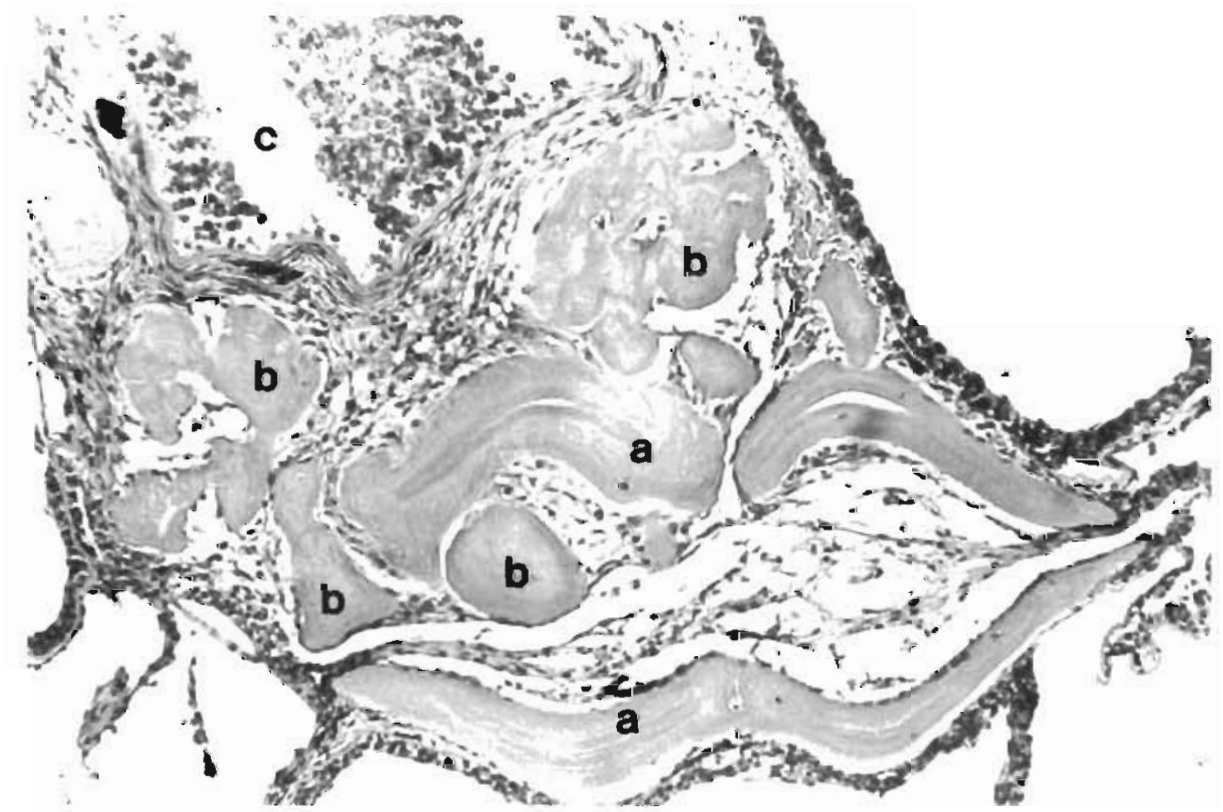




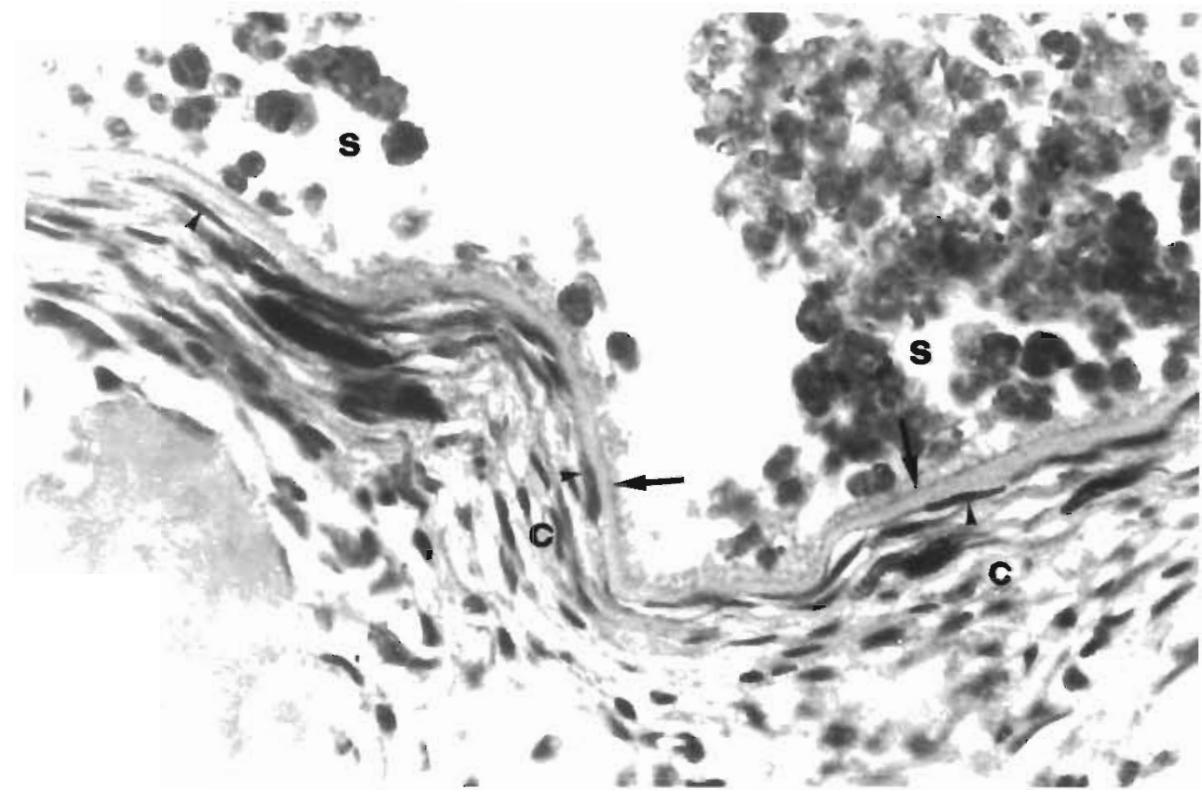

Fig. 9. Cyprinus carpio carpio Part of a Thelohanellus nikolskit plasmodium in the fin. Developing spores (s) are located within a cartilaginous capsule (arrows) formed by hemisegment-forming cells (small arrowheads). Connective tissue (c) rich in collagen. Detached part of the broken hemisegment. H\&E, $\times 750$ nous material is formed by the calcification of deposited collagen. Although the cells constituting the cartilaginous capsule around plasmodia form a less confluent layer, their function is the same as that of the cartilage-forming cells in the fins. We suppose that plasmodium formation in the fins or scales, respectively, is related to the age of the host. It seems possible that in older fish-due to the advanced calcification of finrays - the cartilage is less suitable for plasmodium formation than the scales. This could be the most evident reason why in younger fish the finrays are the exclusive locations and why in older fish the parasite most often develops on the scales and is only seldom located on the fins. This is supported by the observation that plasmodia always develop at the less calcified edge of the scales.

Despite intensive infections found during our survey neither mortality nor disease was recorded. Thelo- hanellus nikolskii parasitizing the scales seems to possess low pathogenicity, presumably because it develops in a less vital organ.

This study shows that a proper evaluation of the validity of closely related species cannot rely on morphological data alone. Morphological and metrical characteristics should be evaluated together with the host, organ and tissue specificity of the given Myxosporea. In this respect only 3 Thelohanellus species (T. nikolskii, T. hovorkai and T. kitauei) of the common carp meet the requirements to be considered separate species. On a morphological basis, however, 2 additional Thelohanellus species described from common carp, T. acuminatus Achmerov, 1955 and $T$. dogieli Achmerov, 1955, can be regarded as valid species. We regard $T$ cyprini Hoshina \& Hosoda, 1957 and T. callisporis Ky, 1971 as junior synonyms of $T$. nikolskii Achmerov, 1955. In a similar way, T. acuminatus Ky,

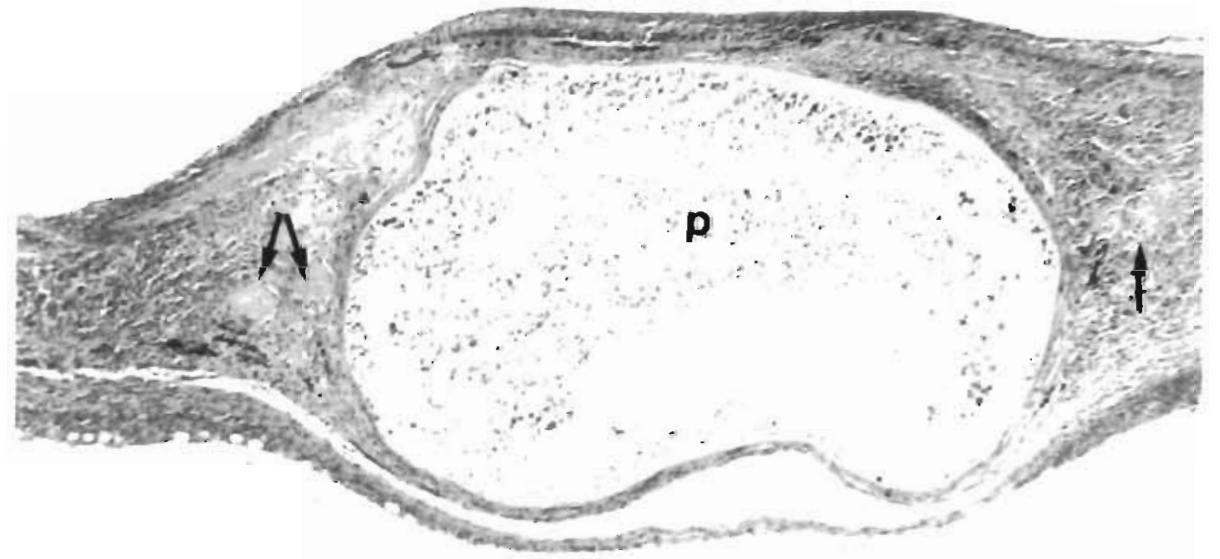

Fig. 10. Enlarged part of Fig. 7 Plasmodium-infected scale. Around the plasmodium ( $p$ ), inside the connective tissue disrupted islets (arrows) of the calcified scale plate are seen. $H \& E, \times 78$ 
1971 should be classified to T. acuminatus Achmerov, 1955 in the future. Further data are needed to support the validity of $T$ amurensis Achmerov, 1955. Also, additional studies are warranted to provide data on whether other Thelohanellus spp. ( $T$. fuhrmanni, $T$ oculileucisci, $T$ pyriformis and Thelohanellus sp.) described from other cyprinids but reported to occur in the common carp (Petrushevsky \& Bauer 1948, Moshu 1983, Donec \& Shulman 1984, Iskov 1989) actually infect the latter fish species.

Acknowledgements. The authors thank Dr I. D. Trombitsky, Fisherres Research Station of Moldova, for his advice and critical comments on the manuscript. The work of K.M. was supported by the U.S.-Hungarian Joint Fund, J.F. No. 326

\section{LITERATURE CITED}

Achmerov AC (1955) Ways of the origin of Myxosporidia species of the genus Thelohanellus Kudo from Amur wild carp. Dokl Akad Nauk SSSR 105:1129-1132 (in Russian)

Achmerov AC (1960) Myxosporidia of fish in the basin of River Amur In: Rybnoe khozyaistvo vnutrennikh vodoemov Latviiskoi SSR 5:239-308 (in Russian)

Bauer ON (1948) Parasites of fish in river Jenisej. lzv VNIORH 27:97-156 (in Russian)

Cirković M (1986) Myxospondiosis of the common carp fingerlings. Doctoral thesis, Veterinary Faculty, Beograd (in Serbian)

Desser SS, Molnái K, Weller I (1983) Ultrastructure of sporogenesis of Thelohanellus nikolskii Achmerov, 1955 (Myxozoa: Myxosporea) from the common carp, Cyprinus carpio. J Parasitol 69:504-518

Donec ZS, Shulman SS (1984) Parasitic protozaa. Phylum Cnidosporidia. In: Bauer ON (ed) Key to determination of parasites of freshwater fishes of the USSR, Vol I. Publ House Nauka, Leningrad, p 88-251 (in Russian)

Dyková I, Lom J (1988) Review of pathogenic myxosporeans in intensive culture of carp (Cyprinus carpio) in Europe. Folia Parasitol 35:289-307

Egusa S, Nakajima K (1981) A new Myxozoa Thelohanellus kitauei, the cause of intestinal giant cystuc disease of carp. Fish Pathol 15:213-218

Hacmanjek M (1985) Thelohanellosis, a very frequent disease of Yugoslavian fish farms. Ribarstvo Jugoslavije 40:94-96 (in Serbian)

Hoshina T, Hosoda $\mathrm{S}$ (1957) On a new Myxosporidian species, Thelohanellus cyprini n. sp., parasitic in the fin of Cyprinus carpio. J Tokyo Univ Fish 43:71-73

Iskov MP (1989) Myxosporidia, 4. Sporozoa, Cniclosporidia and Myxosporidia. In: Fauna Ukraini, Vol 37. Publ House Naukova Dumka, Kiev, p 212 (in Russian)

Jeney $G$ (1979) The occurrence of Thelohanellus dogieli Achmerov, 1955 (Myxosporidia) on carp (Cyprinus carpio) in fish ponds in Hungary. Parasitol Hung 12:19-20

Responsible Subject Editor: W. Körting, Hannover, Germany
Jeney $\mathrm{G}$. Molná $K$ (1981) Thelohanellosis of the common carp in Hungary. In: Fish, pathogens and environment in European polyculture. Proceedings of an lnternational Seminar. Haltenyésztisi Kutato Intézet, Szarvas, p 205-209 (in Russian)

Kitaue K (1980) Intestinal giant cystic disease affecting the carp, caused by Thelohanellus sp. Fish Pathol 14:145-146

Ky $H$ (1971) Some freshwater myxosporean species from North Vietnam. Acta Protozool 8:283-298

Lanzing WJR (1976) The fine structure of fins and finrays of Tilapia mossambica (Peters). Cell Tiss Res 173:349-356

Lanzing WJR, Wright RG (1976) The ultrastructure and calclfication of the scale of Tilapia mossambica. Cell Tissue Res $167: 37-47$

Molnár K (1982) Biology and histopathology of Thelohanellus nikolskii Achmerov, 1955 (Myxosporea, Myxozoa), a protozoan parasite of the common carp (Cyprinus carpio). Z Parasitenkd 68:269-277

Molnár K (1994) Comments on the host, organ and tissue specificity of fish myxosporeans and the types of their intrapiscine development. Parasitol Hung 27:5-20

Molnár K, Kovács-Gayer É (1981-1982) Occurrence of tho species of Thelohanellus (Myxosporea: Myxozoa) of FarEast origin in common carp populations of the Hungarian fish farms. Parasit Hung 14:51-55

Molnár K, Kovács-Gayer E (1986) Biology and histopathology of Thelohanellus hor orkai Achmerov, 1960 (Myxosporea, Myxozoa), a protozoan parasite of the common carp (Cyprnus carpio). Acta Vet Hung 34:67-72

Moshu A (1993) Myxosporidia of cultured fishes in Moldovian fish farms. In: Abstracts of XI Conference of the Ukrainian Society of Parasitology. Academy of Science of Ukraine, Kiev, p 96-97 (in Russian)

Petrushevsky GP. Bauer ON (1948) Parasitic diseases of fish in Siburia and their economic and medical significance. Izv VNIORH 27:195-216 (an Russian)

Rhee JK, Kim JO, Kim GP, Park BK (1990a) Prophylactic and therapeutic studies on intestinal giant cystic disease of the Israel carp caused by Thelohanellus kitauei. I. Course of formation and vanishment of the cyst. Korean J Parasitol 28:183-194 (in Korean, with English summary)

Rhee JK, Kim OJ, Park BK (1990b) Prophylactic and therapeutic studies on intestinal giant cystic disease of the Israel carp caused by Thelohanellus kitauei. II. Effect of physical and chemical factors on $T$. kitauei spores in vitro Korean J Parasitol 28:241-252 (in Korean with English summary)

Shulman SS (1962) Class Cnidosporidia. In: Bychowsky BE (ed) Key to determination of parasites of freshwater fishes of the USSR. Publ House Acad Sci USSR, MoscowLeningrad, p 47-130 (in Russian)

Shulman SS (1966) Myxosporidia of fish fauna of the USSR Publ House Nauka, Leningrad, p 508 (in Russian)

Trombitsky ID, Golovina NA, Sheinin ME (1983) Thelohanellosis of common carp. E I CNIITTEIRH 8:12-15 (in Russian)

Trombitsky ID, Sheinin ME, Manja VM (1990) Biology and pathogenicity of Thelohanellus nikolskii. Parazitologiya 24:354-358 (in Russian)

Manuscript first received: June 7, 1996

Revised version accepted: September 10, 1996 